\title{
CSALÁDI GAZDASÁGOK FEJLŐDÉSI LEHETŐSÉGEI
}

\section{Nagyné Demeter Dóra}

\begin{abstract}
Absztrakt: Az átfogó kutatás a mezögazdasági termeléssel foglalkozó családi gazdaságok termelési struktúrában elfoglalt valós pozícióját meghatározására, valamint a változásokat leíró folyamatok alapján a jövőbeli fejlödési lehetőségeiket feltárására irányult. A kutatás során az értékesítési lehetőségeket, valamint a szabályozási környezet változásainak hatásait vizsgáltam. Célom a családi gazdaságok lehetőségeinek és fejlödési lehetöségeink feltárása volt. Az empirikus vizsgálat 2017-ben kezdödött és 2018 tavaszáig tartott. Jelen tanulmányban az alábbi kérdésekre kapott válaszokat ismertetem: Milyen forrásokból kívánják fejleszteni és bővíteni a gazdaságukat? Milyen humán eröforrás tényezők játszhatnak ebben szerepet?
\end{abstract}

Abstract: The aim of our project is to study farms in that mobilize labour and capital for the sake of agricultural production. During our projects we have to examine the following topics: opportunities of sales in food commerce and taking part in short supply chains and effect of legal system change to the function and developed of family farms. I gained information from family farms and other agricultural producers throw an on-line based empirical survey from 2017 to spring 2018. This current study represented the answer about the following question: How and by which sources help the farmers to develop and extend their farms? Which human factors have a role in farming?

Kulcsszavak: családi gazdaságok, külsö erőforrások, fejlesztés, értékesítési lehetőségek

Keywords: family farms, farm extend, human factors, development, sales opportunity

\section{Bevezetés}

Az elmúlt évtizedek kutatási alapján a családi és kis gazdaságok kulcsfontosságú szerepet játszanak a környezeti fenntarthatóságban, a gazdálkodók megélhetésében (Chappell et al., 2013). Mivel a kisbirtoktesttel rendelkező gazdaságok esetenként a nagyobb gazdaságok hozamait felülmúlhatják, a jövedelmezőségi problémák, a termelési tényezőkhöz való korlátozott hozzáférés és a termelési inputok kérdésének megoldására való koncentrálás indokoltabb mint a modell teljes reformja (HLPE, 2013. 43.p.).

Az állami támogatások csökkenése, a társadalmi-politikai és gazdasági az egyenlőtlenség és az agrárszektorban zajló konszolidáció, fokozódó kihívásokat jelentenek a családi gazdálkodók számára. Ezek valószínüleg nem kezelhetöek anélkül, hogy a helyi és a nemzetközi egyenlötlenségek ismerte és kezelése nélkül (Chappell et al., 2013; Constance et al., 2014). A piacokhoz, hitelkonstrukciókhoz, oktatáshoz való hozzáférés hiánya, a helyi szintü agrárkutatások minősége és disszeminációja jelentős tényező a családi gazdaságok számára (BerdegueFuentealba, 2011).

A kis- és közepes családi gazdaságok előtt álló jövőbeli kihívások közé tartozik a természeti erőforrásokhoz való hozzáférés, a piaci érdekérvényesítő képesség erösítése, az összefogás és az innováció szükségessége (Davidova-Thomson, 2014).

A 2008-as KAP reform óta a termeléstől elkülönített, szabadabb felhasználású források megjelenésével, elindult a mezögazdasági üzemek szerkezetváltása (Richardson, 2005; Midmore, 2011). Ezek a változások magágukban foglalták egy átfogóbb postproduktivista multifunkcionális vidéki gazdaság kialakulását, mely 
különösen a térbeli, szociális és a farmok háztartásainak összefüggésében kezdődött el (Leck et al., 2014). Noha néhány kritikus azt sugallja, hogy a reformok gátolták termelékenységet javító innovációk befogadását/alkalmazását, valamint a gazdaságok hatékonyságának további növelését (Rickard, 2012).

A világ teljes mezőgazdasági területének $75 \%$-át családi gazdaságok müvelik, számuk minden országban egyaránt magas, ebből az következik, hogy felelősek a világ agrár és élelmiszer gazdasági termelésének döntő hányadáért. (Lowder et al., 2016). A családi gazdaságok esetén minden területi (globális, európai, nemzet állami) szinten fontos a kis méretü, 2 ha alatti, egyéni, kis gazdaságokat és a családi gazdaságokat megkülönböztetni. Míg az előzöeket elsősorban szociális célú gazdálkodás jellemzi, utóbbiak a termelési struktúra fontos alapkövei. Bár a két kategória között lehetnek átfedések, míg a világ teljes mezőgazdasági a kis gazdaságok csupán 12\%-át müvelik. Ezért vélhetően nem befolyásolják nagy mértékben a világ élelmiszertermelését $\mathrm{A}$ családi gazdaságok által müvelt területek minden ország esetében konzekvensen magas értéket mutattak, így a világ élelmiszer termelésében döntő szerepük van. Ezek a becslésen alapuló eredmények reprezentálják a két csoport élelmezésben és mezőgazdasági termelésben betöltött szerepét. Világ viszonylatban a közép és magas jövedelmezőségi kategóriába tartozó országokban utóbbi csoporton belül növekedés következett be. (Sarah et.al, 2016). A globális élelmiszerellátó láncok jelentős átalakulásának ellenére, a családi gazdálkodók még mindig jelentős mértékben hozzájárulnak a globális mezőgazdasági termeléshez (kb. 2,2 trillió USD) (World Bank, 2014)

Az Európai Unióban 10,8 millió mezőgazdasági profilú gazdasági egység müködik, amelyek 174,4 millió hektáron gazdálkodnak. Noha az európai agrármodell a családi kis- és közepes gazdaságokra épül, az üzemszerkezeti struktúráját a nagygazdaságok és kisgazdaságok kettősége jellemzi. Az európai átlagos birtokméret 16,1 hektár, a csak családi munkaeröt foglalkoztató farmok 9,3 hektárosak, míg a fizetett munkaerőt alkalmazó gazdaságok 148,7 hektárosak.

A munkaerő-felhasználás szempontját tekintve a teljes mezőgazdasági munkaerő felhasználás 78,8 százalékát a csak családi munkaeröt igénybe vevő gazdaságok teszik ki. 90\% feletti Görögország, vagy Románia esetén, azaz itt alig van fizetett alkalmazottja a gazdaságoknak. A fizetett bérmunka dominál a szlovák, cseh farmereknél, míg a német, dán, francia esetben vegyes modell müködik (EUROSTAT, 2016). Az EU-28-ban 10,7 millió farmer vezeti a 10,8 millí́ gazdaságot. Ez közel 3,3 millió gazdálkodót jelent. A déli országokban az arányuk a 40 százalékot is meghaladja. A generációváltás óriási kihívást jelent egész Európában, hiszen a 35 év alattiak aránya csupán 5,8\%, míg a 65 év felettieké $31,3 \%$ (EU Briefs, 2013).

A családi gazdaságok definiálása mind világviszonylatban mind nemzeti szinten sokrétü. Átfogó nemzetközi kutatások alapján, mely családi gazdaságok fogalmát tanulmányozta, 36 különféle definíciót találtak. Minden definíció megegyezetl abban, hogy családi gazdaságok a családon belüli munkaeröt dinamizálják és farmol a család vezeti (Garner-de la $O$ Campos, 2014). Néhány meghatározásban maximalizálták azt a birtokméretet amelyen túl már nem tekinthetö családi 
gazdaságnak a vállalkozás. Továbbá a maximalizálták a háztartás jövedelmén belül a nem mezőgazdasági termelésböl származó hányadot. A farmon kívüli és a farmon belüli jövedelmet képező tevékenységek közötti kapcsolat komplex lehet. A támogatás vagy a támogatások igénylése a farmon belüli tevékenységekhez vagy versenyezhet vagy kiegészítheti a jövedelemtermelő tevékenységekkel (Morris et al., 2017).

Magyarországon az egyéni gazdaság statisztikai fogalom, míg a családi gazdaság agrár-ökonómiai, jogi és adózási aspektusban definiálható. Mivel egyelöre nincs üzemszabályozási törvény, amely egzakt módon meghatározná az egyes méretkategóriák közti különbségeket, a kis- és a nagy-gazdaságok összehasonlítása vállalatgazdasági, földtulajdoni, vagy versenyképességi vonatkozásában nehézkes (Kurucz, 2012; Alvincz, 2013; Némethné, 2015).

A magyar szakirodalomban előbbiek miatt a családi gazdaságok fogalmi lehatárolása, hasonlóan a nyugat-európai gyakorlathoz, több megközelítésböl történik. A definíciókat elemezve a családi gazdaságon általában azokat a gazdaságokat értik, amelyek döntően a családi munkaerőre alapozva fő vagy mellékállásban jövedelemszerzési céllal hosszú távú gazdálkodásra rendezkednek be. Az irányítás a család kezében összpontosul a földtőke és az eszközállomány zöme saját tulajdonú, ugyanakkor a gazdaságossági szempontokat is szem elött tartva jelentős föld, munka vagy eszközbérleményt, illetve szolgáltatást vesz igénybe a gazda. Továbbá a gazdálkodást több generáción keresztül öröklődő életformának tekinti (Nagyné Demeter, 2009, Csete, 1992). Hosszabb távon a vidékfejlesztés, a vidéki életforma megörzésének alapelemei ezek a gazdaságok.

\section{Anyag és módszer}

\subsection{Vizsgálati mintaterület}

Jelen tanulmányban közölt részeredmények egy átfogó kutatásból származnak. A kutatás 2017 szeptemberében kezdődött, mezőgazdasági termeléssel foglalkozó családi gazdaságok termelési struktúrában elfoglalt pozíciójának meghatározására irányult. Továbbá a jövöbeli fejlödési lehetőségeiket feltárására. A fö cél olyan információk felderítése, melyek a jövőbeni fejlesztési koncepciók alapját adhatják. A vizsgálati minta terület Heves, Komárom-Esztergom, valamint Nógrád megyére terjed ki kiegészülve a három megyével határos felvidéki járással. A megfigyelt alapsokaságot a vizsgálatban a mezögazdasági termelók alkotják, az elemzési egységet a családi gazdaságok. A mintavétel során a véletlen mintavétel módszere alkalmazható, a várható elemszám a teljes mintát adó gazdaságok számának 10\%-a.

Jelen tanulmány a Heves megyei minta terület eredményeit dolgozza fel. A vizsgálat során 99 gazdálkodót kérdeztünk le kérdöív segítségével. A megyében a regisztrált családi gazdaságok száma 420 darab. Így a minta a 10\%-os reprezentativitási határt elérte. A kérdőív az általános kalibráló adatokon túl tartalmazta a gazdálkodás körülményeivel, földhasználattal, valamint a külső eröforrások bevonásával kapcsolatos kérdéseket. 


\subsection{Az elemzésben használt módszerek}

A másodlagos elemzéseket a vizsgálati minta alapvető jellemzöit értékelö, számszerüsítő egyszerü statisztikai vizsgálatok után végeztük el. Az egyszerü egyetlen változó attribútumainak megoszlását összegző statisztikai próbák mellett a leíró statisztika általában véve a vizsgált adatok összegzését szolgálja. Az általunk is alkalmazott leíró statisztikai módszer a gyakoriság vizsgálat, amelyben a változók relatív és kumulatív eloszlását elemeztük és ábrázoltuk egy adott kérdéskörön belül. A többszörös válaszadások esetében az elemzést gyakorisági- és kereszttáblázatok létrehozásával végeztük el, az általunk elöre definiált többszörös válaszadások csoportjai, szettjei alapján.

A nominális típusú változók közötti kapcsolatot, amely elösegítette a hipotéziseink vizsgálatát, asszociációs mutatószámmal jellemeztuik. Az elemzés során az adatokat kereszttáblákba rendeztük, a gyakoriságok elhelyezkedése alapján feltételezett oksági kapcsolatok érvényességét, konkrétan khí-négyzet próbával ellenöriztük. A szignifikancia szintet a konvencionális értéken állítottuk be $(\mathrm{p}<0,05)$. A próba a változók közötti kapcsolat „valódiságát" dönti el, semmit nem mond azonban a kapcsolat irányáról vagy erősségéről. A kapcsolatok és a megfigyelt folyamatok irányát nem tudtuk meghatározni az alacsony mintaszám miatt, az ilyen irányú statisztikai elemzések téves következtetések levonását eredményezték volna.

\section{Eredmények és értékelésük (például)}

\subsection{A vizsgálati minta jellemzöi}

A kérdőives vizsgálatba bevont gazdálkodók ( $\mathrm{n}=99$ fö) a nemenkénti megoszlás alapján a válaszadók 74,7 százaléka férfi, és mindössze 25,3 százaléka volt nő. Ez arra enged következtetni, hogy a nök körében a gazdálkodói életforma bár jelen van, de csak ritkán vezetik maguk a gazdaságokat. Legtöbbször, mint kisegítők, vagy alkalmazottak vannak jelen a termelésben

Az életkor szerinti megoszlás kedvezőtlen tendenciákat mutat, az átlag életkor 52 év körül mozog és a válaszadók 11\%-a volt 35 év alatti, a 60 év felettiek 24\%ban voltak jelen (l.ábra). A legfiatalabb válaszadó 21 éves volta legidősebb 82 . A 2 országos átlagtól ezek a megyei adatok kedvezőbb képet mutatnak.

A gazdálkodás idôtartamát tekintve a válaszadók 59,6 százaléka több mint 10 éve foglalkozik élethivatásszerüen föállásban vagy mellékállásban gazdálkodással. $\mathrm{Az}$ öt és tízéves idöintervallumba sorolható válaszadók száma 23,2\% a kevesebb. mint öt éve gazdálkodók aránya $17,2 \%$. Ez kedvezö alapot nyújthat a vélemény és reagálás vizsgálat tárgyát képező kérdések értékeléséhez. A gazdálkodás jellege szerint több a növénytermesztők kerültek túlsúlyba (55\%), öket a megyében található szőlő ültetvények magas területi arányának köszönhetően a kertészeti ágakban gazdálkodók (18\%) követték. Az állattartók és a vegyes gazdálkodók arányosan jelentek meg a mintában. 
1. ábra: A válaszadók életkor szerinti megoszlása

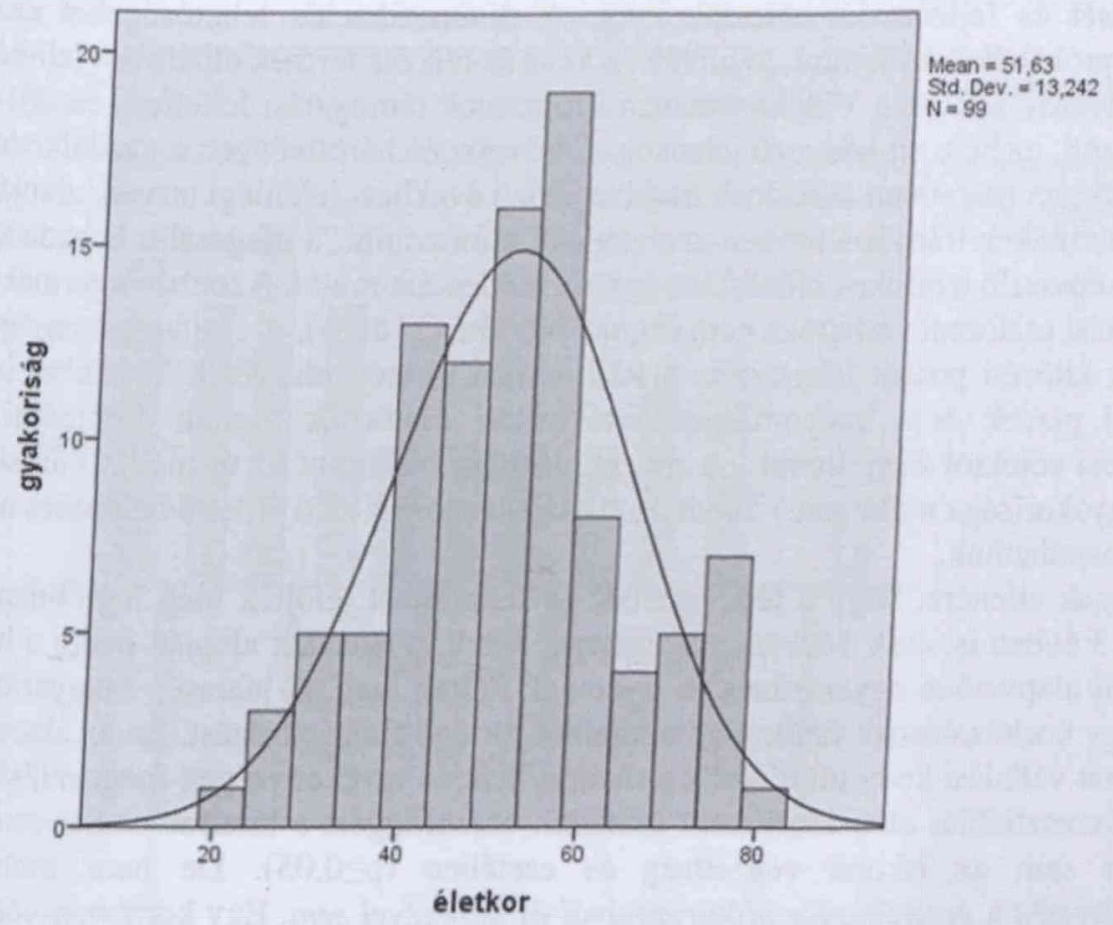

Forrás: Saját szerkesztés, empirikus kutatások alapján

A humán erőforrás minősége alapvető fontosságú, ezért az iskolai végzettséget is vizsgáltuk. Statisztikai összefüggés nem mutatható ki az iskolai végzettség és a gazdálkodás típusa között. Azonban a tendenciákat érdemes megfigyelni:

- csak a növénytermesztők dominálnak esetében a középfokú, nem szakirányú végzettséggel rendelkezők,

- az állattartók és a kertészek esetében a szakirányú végzettségüek magasabb arányban vannak jelen, közép és felsőfok esetében egyaránt,

- a felsőfokú végzettségüeken belül a szakirányú végzettség dominál, minden gazdálkodási jellegnél.

$\mathrm{Az}$ iskolai végzettségek megoszlását tekintve a vizsgálati minta populáció kedvezőbb képet mutatott az országos átlagnál. Ez a fiatalabb válaszadók magasabb arányának köszönhető.

\subsection{Fejlesztési lehetőségek}

A kutatási egyik célja, hogy a gazdaságok külső erőforrás bevonását vizsgálja. Megvizsgáltuk, hogy a tevékenységük mennyire diverzifikált, a müködéshez fejlesztéshez vesznek-e igénybe hitelt (az utóbbi években több kifejezetten gazdálkodóknak szóló hiteltermék jelent mega piacon), illetve, hogy a müködésükhöz, fejlődésükhöz igényelnek-e oktatást, képzést. Az vizsgált kérdések esetében arra is választ kerestünk, hogy a gazdálkodás jövőbeni céljaitól mennyire függ a külső erőforrás kereső magatartás. 
A gazdaságok alapvetően az elmúlt 3 évben a mezőgazdasági tevékenységek fenntartását és fejlesztését célozták meg. A diverzifikációs lehetőségeket csak kevesen próbálták kihasználni, leginkább a kész és félkész termék elöállítást jelölték meg. Figyelembe véve a Vidékfejlesztési Programok támogatási lehetöségeit 20142020 között, ez nem túl kedvező jelenség. A következő három évben a gazdálkodók tevékenységei hasonlóan alakulnak majd az előző évekhez, jelenlegi terveik alapján. A kész termékek irányába többen szeretnének elmozdulni, a magasabb hozzáadott értéket képviselő termékek előállítása pozitív tendenciát mutat. Azonban a termékek értékesítési csatornái várhatóan nem fognak bövülni (2. ábra). A családi gazdaságok számára kitörési pontot jelenthetne a REL-ekben történő részvétel. Továbbra is a termelöi piacok és a hagyományos értékesítési csatornák fognak dominálni, a fejlesztési céloktól függetlenül. (A mozgó árusítás, valamint az út melletti árusítás említi gyakorisága nulla volt.) Tehát az ellátási láncokba való érdemi belépésre nem következtethetünk.

Annak ellenére, hogy a fejlesztéshez és fenntartást jelölték meg legtöbben az elmúlt 3 évben is, csak 14\%-uk vett igénybe hitelt. Válaszaik alapján pedig a hitel felvételt alapvetően egyszerünek és gyorsnak ítélték meg. A jelenség magyarázata az, hogy kockázatosnak ítélik meg a hitelböl történő finanszírozást. Ez az alacsony kockázat vállalási kedv tükröződik a diverzifikációs tevékenységek megoszlásában is. A kereszttáblás elemzések nem mutattak összefüggést a hitelfelvétellel sem az életkor sem az iskolai végzettség és esetében ( $\mathrm{x} \geq 0,05)$. De nem mutatott összefüggést a gazdálkodás idôtartamával és jellegével sem. Egy korábban végzett 2009-es saját kutatás eredménye is azt mutatta, hogy a hitel felvételi hajlandóság alacsony ennél a gazdálkodói csoportnál. A gazdálkodás időtartamától, jellegétől nem függött a hitelfelvételi hajlandóság akkor sem (Nagyné Demeter, 2009). 
2. ábra: Az értékesítési csatornák alakulása a fejlesztési tervek függvényében, a válaszok megoszlásának arányában

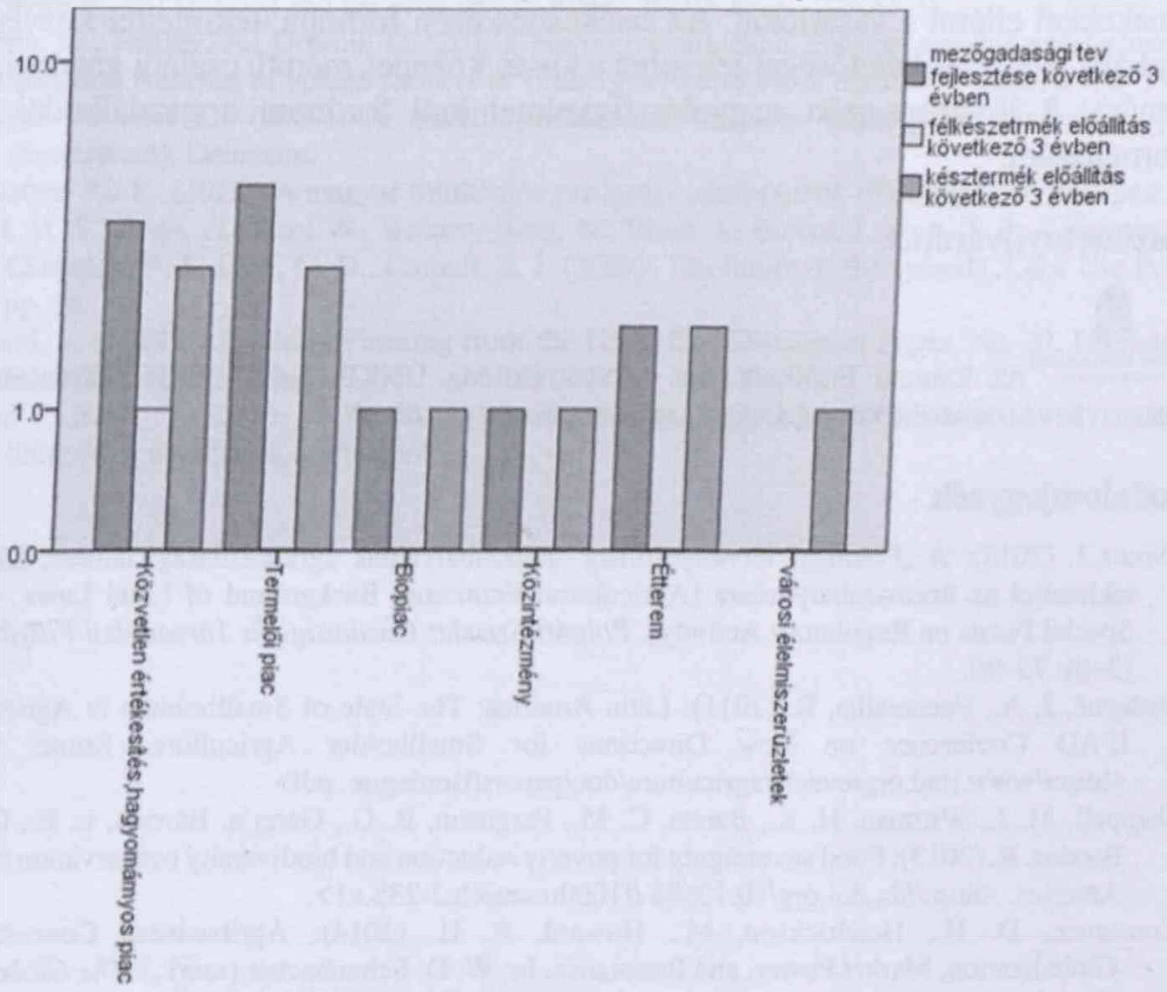

$\mathrm{n}=\mathbf{8 1}$

Forrás: Saját szerkesztés, empirikus kutatások alapján

\section{Következtetések, összegzés, záró megjegyzések, záró gondolatok}

A kutatás részeredményei rámutattak, hogy a gazdálkodók külső erőforrások bevonásánál, a KKV-kal ellentétben, a banki hitelezést nem használják ki. Ez azonban a diverzifikációs képességeiket erősen determinálja, noha ezeket a lehetőségeket alapvetően keresik. Azonban a kockázatvállalási hajlandóságuk nagyon alacsony. Mind a fiatalabb mind az idősebb gazdálkodók körében. A korábbi kutatási eredményt összevetve a jelenlegivel, azt mondhatjuk, hogy ez a probléma már közel egy évtizede jelen van.

A gazdaságok jövőjét alapvetően befolyásolja, hogy a külső erőforrásokat miként tudják megszerezni és hasznosítani. A folyton változó piaci kondíciók és követelmények, a gazdasági környezet labilitása és a gazdaságok tőke szegénysége egyaránt indokolja külső források igénybevételét. A vállalkozói szellem, a gazdaságon belüli diverzifikációs képesség, a források fejlesztése, vagy a tevékenységi kör bővítése kritikusan befolyásolhatja az azonos korú családi menedzsmenttel rendelkező gazdaságok túlélési képességeit.

A fejlesztések körének tervezésekor az EU által preferált értékesítési csatornákban nem gondolkodnak a gazdálkodók. Ez alapvetően problémát jelent, 
mert a REL-ek fenntartása hosszabb távon csak nagyobb mennyiségü termékekkel valósulhat meg, melyet a kis méretü gazdaságok (0,5-2 hektár) nem tudják majd termékekkel ellátni a vásárlókat. Az értékesítés ezen formája, tekintettel közvetlen és lokális jellegére, lehetőséget jelenthet a kis és közepes méretü családi gazdaságok számára. A jövöben ezért nagyobb figyelmet kell fordítani a gazdálkodói kör informálására.

\section{Köszönetnyilvánítás}

". Mininntuluma AZ EMBERI ERÖFORRÁSOK MINISZTÉRIUMA ÚNKP-17-4-13 EKE KÓDSZÁMÚ Ú] NEMZETI KIVÁlósÁg PROGRAMJÁNAK TÁMOGATÁSÁVAL KÉSZÜlT"

\section{Irodalomjegyzék}

Alvincz J. (2013): A „Földügyi törvénycsomag” jogszabályainak agrárgazdasági háttere, különös tekintettel az üzemszabályozásra [Agricultural Economic Background of Land Laws - with Special Focus on Regulatory Activity]. Polgári Szemle: Gazdasági És Társadalmi Folyóirat, 9 (3-6): 73-90.

Berdegué, J. A., Fuentealba, R. (2011): Latin America: The State of Smallholders in Agriculture. IFAD Conference on New Directions for Smallholder Agriculture. Rome: IFAD. 〈http://www.ifad.org/events/agriculture/doc/papers/Berdegue .pdf>

Chappell, M. J., Wittman, H. K., Bacon, C. M., Ferguson, B. G., Garcı'a, Barrios, L. E., García Barrios, R. (2013): Food sovereignty for poverty reduction and biodiversity conservation in Latin America. 〈http://dx.doi.org/10.12688/f1000research.2-235.vl>

Constance, D. H., Hendrickson, M., Howard, P. H. (2014): Agribusiness Concentration: Globalization, Market Power, and Resistance. In: W. D. Schanbacher (szerk.): The Global Food System: Issues and Solutions. Santa Barbara, CA: ABC-CLIO.

Csete L. (1992): Az egyéni magángazdaságok szerepe és esélyei Magyarországon. A kompoli tanácskozás anyaga. Kompolt, 1992. november 5. Kompolt, Gödöllöi Agrártudományi Egyetem Mezögazdasági Kutatóintézet.

Davidova S., Thomson K. (2014): Family farming in Europe: Challenges and prospects, Policy Department B: Structural and Cohesion Policies, In-depth Analysis, European Union.

EU Agricultural Economics Brief (2013): Structure and dynamics of EU farms: changes, trends and policy relevance 2013 No. 9 . October.

Eurostat (2016) Agriculture statistics - family farming in the EU. $<$ http://ec.europa.eu/eurostat/statistics-explained/index.php?title=Agriculture _statisticsfamily_farming_in_the_EU\&oldid=352405>

Garner, E., de la O Campos, A. (2014): Identifying the "family farm": An informal discussion of the concepts and definitions. ESA Working Paper 14-10. Rome: FAO.

Happe, K. (2004): Agricultural policies and farm structured: agent-based modelling and applicatio? to EU policy reform. In: Studies on the Agricultural and Food Sector in Central and Easter Europe, vol. 30. Institute of Agricultural Development in Central and Eastern Europe, Halle.

HLPE (2013). Investing in smallholder agriculture for food security. A report by the High Level Pantof Experts on Food Security and Nutrition of the Committee on World Food Security. Rome HLPE. 〈http://www.deza.admin.ch/ ressources/resource_en_225682.pdf>

Kurucz M. (2012): Gondolatok egy üzemszabályozási törvény indokoltságáról. Gazdálkodás, 56 (2) $118-138$.

Leck, C., Evans, N., Upton, D.(2014): Agriculture - who cares? An investigation of 'care farming' if the UK. J. Rural Stud, 34: 313-325. 
Lowder S. K, Skoet J., Raney T. (2016): The Number, Size, and Distribution of Farms, Smallholder Farms,and Family Farms Worldwide. World Development, 87: 26-27.

Midmore P. (2011): Food and the economy in Wales. Welsh Econ., 22: 29-31.

Morris, W., Henley, A., Dowell, D. (2017): Farm diversification, entrepreneurship and technology adoption:Analysis of upland farmers in Wales. Journal of Rural Studies, 53 (2017): 135-136.

Nagyné Demeter D. (2009): A családi gazdálkodás helyzete Hajdú-Bihar megyében. (PhD disszertáció). Debrecen.

Némethné Pál K. (2015): A magyar földkérdés gazdasági nézőpontból. (Kézirat) GKI, Budapest. Reed, M. S., Bonn, A., Slee, W., Beharry-Borg, N., Birch, J., Brown, I., Burt, T. P., Chapman, D., Chapman, P. J., Clay, G. D., Cornell, S. J. (2009): The future of the uplands. Land Use Policy pp. 26.

Rickard, S. (2012): Liberating Farming from the CAP. IEA Discussion Paper, No. 37. Institute of Economic Affairs, London.

World Bank (2014): World Development Indicator: Structure of output. <http://wdi.worldbank.org/table/4.2>. 